\title{
A first-principles study of the structure, electronic properties, and oxygen binding of $\mathrm{FeO} / \mathrm{Pt}(111)$ and $\mathrm{FeO}_{2} / \mathrm{Pt}(111)$
}

\author{
SUN Dapeng, LI Weixue* \\ State Key Laboratory of Catalysis, Dalian Institute of Chemical Physics, Chinese Academy of Sciences, Dalian 116023, Liaoning, China
}

\section{A R T I C L E I N F O}

Article history:

Received 26 January 2013

Accepted 15 March 2013

Published 20 May 2013

Keywords:

Ultra thin oxide film

Superstructure

Corrugation

Charge transfer

Work function

\begin{abstract}
A B S T R A C T
The ultrathin oxide films of bilayer $\mathrm{FeO}$ and trilayer $\mathrm{FeO}_{2}$ superstructures on $\mathrm{Pt}(111)$ with periodicity of $(\sqrt{84} \times \sqrt{84}) R 10.9^{\circ}$ are studied in detail by density functional theory, and the corresponding structural properties, electronic properties, and oxygen activities in different domains (FCC, HCP, and TOP) are calculated. It is found that for both superstructures, the in-plane lattice constants slightly increase in the order FCC $<\mathrm{HCP}<\mathrm{TOP}$. The calculated order of the surface corrugation (O-Fe rumpling) is FCC > HCP > TOP for FeO/Pt(111), and FCC > TOP > HCP for $\mathrm{FeO}_{2} / \mathrm{Pt}(111)$. The surface electrostatic potentials and the binding energies of the surface oxygen atoms are found to follow the same order as the surface corrugation. There is net charge transfer from the supported $\mathrm{FeO}$ film to the Pt substrate for $\mathrm{FeO} / \mathrm{Pt}(111)$, and the calculated oxidation state of iron is +2.36 . In contrast, for $\mathrm{FeO}_{2} / \mathrm{Pt}(111)$, there is charge transfer from the Pt substrate to the supported $\mathrm{FeO}_{2}$ film, and the calculated oxidation state of iron is +2.95 (ferric state). Compared with $\mathrm{Pt}(111)$ ), the change of the surface work function of $\mathrm{FeO} / \mathrm{Pt}(111)$ is negligible, while it is $1.24 \mathrm{eV}$ for $\mathrm{FeO}_{2} / \mathrm{Pt}(111)$. The role of the surface dipole of the supported oxide film and the charge transfer of the ultrathin oxide film are discussed.
\end{abstract}

(C) 2013, Dalian Institute of Chemical Physics, Chinese Academy of Sciences. Published by Elsevier B.V. All rights reserved.

\section{Introduction}

Ultrathin oxide films grown on metal substrates have attracted considerable attention in past decades because of their unique structural and electronic properties, and their potential applications in many areas [1-10]. Depending on the preparation conditions, films of several atomic layers can form complex superstructures that are completely different from the bulk materials [11-19]. These structures have significantly different surface geometries, stoichiometries and electronic properties. As a type of reverse model system and promising new material, metal oxide thin films, e.g., $\mathrm{ZnO}, \mathrm{MgO}, \mathrm{TiO}_{2}$, and $\mathrm{NiO}$, on metal substrates have been extensively studied in surface science research as electronic devices and as heterogeneous catalysts.

Among ultrathin films, iron oxide films grown on Pt have attracted special interest, especially in their surface structures, magnetic properties, and model catalytic reactions $[11,12,17,18,20-30]$. Well-defined bilayers of $\mathrm{FeO}$ on $\mathrm{Pt}(111)$ (FeO/Pt) have been prepared in ultra-high vacuum (UHV) chambers and carefully characterized by scanning tunneling microscopy (STM) and low-energy electron diffraction (LEED). At one monolayer load of $\mathrm{Fe}$, different concomitant $\mathrm{FeO} / \mathrm{Pt}(111)$ structures, such as $(\sqrt{84} \times \sqrt{84}) R 10.9^{\circ}$ and $(\sqrt{91} \times \sqrt{91}) R 5.2^{\circ}$, have been observed $[11,12]$. The superstructures lead to the formation of large surface Moiré patterns in STM images because of the lattice mismatch between the oxide

\footnotetext{
* Corresponding author. Tel: +86-411-84379996; Fax: +86-411-84694447; E-mail: wxli@dicp.ac.cn

This work was supported by the National Natural Science Foundation of China $(21225315,21173210)$ and the National Basic Research Program of China (973 Program, 2013CB834603).

DOI: 10.1016/S1872-2067(12)60580-4 | http://www.sciencedirect.com/science/journal/18722067 | Chin. J. Catal., Vol. 34, No. 5, May 2013
} 
film and substrate. The different domains in the Moiré pattern can have significantly different structural and electronic properties because of the variation of the registration between the grown thin film and metal substrate. Moreover, these domains affect the corresponding activity of exposed surface oxygen atoms and chemical reactions on the surfaces. These structures are sensitive to the preparation conditions, especially the temperature and the oxygen partial pressure [18]. For example, bilayer $\mathrm{FeO}$ is further oxidized at elevated oxygen potential, and there is evidence for trilayer $\mathrm{O}-\mathrm{Fe}-\mathrm{O}$ film formation $\left(\mathrm{FeO}_{2} / \mathrm{Pt}(111)\right)[22,31]$.

Despite extensive experimental studies, the computational study of these superstructures is prohibitive because of the large supercell of the Moiré pattern [20,21,32,33]. This prevents the microscopic understanding of the function of these ultrathin oxide films. It is still unclear how the local registry of the different domains affects the surface corrugation, electronic properties (oxidation state of iron and the work function change), and oxygen activity. In particular, how the properties and oxygen activity change when the polar FeO/Pt(111) surface is oxidized to nonpolar $\mathrm{FeO}_{2} / \mathrm{Pt}(111)$. To address these questions, we report a detailed density functional theory study of $\mathrm{FeO} / \mathrm{Pt}(111)$ and $\mathrm{FeO}_{2} / \mathrm{Pt}(111)$ based on the realistic $(\sqrt{84} \times \sqrt{84}) R 10.9^{\circ}$ superstructure found by experiment. The structural properties, electronic properties, and oxygen activity of $\mathrm{FeO} / \mathrm{Pt}(111)$ and $\mathrm{FeO}_{2} / \mathrm{Pt}(111)$ are investigated and analyzed in detail.

\section{Computational details}

Spin-polarized density functional theory calculations were performed using the Vienna ab-initio simulation package (VASP) [34,35] with all-electron projected augmented wave (PAW) potentials [36,37] and the Perdew-Wang 91 (PW91) [38] exchange-correlation functional. The wave function was expanded by plane wave with kinetic cutoff of $400 \mathrm{eV}$ and density cutoff of $800 \mathrm{eV}$. During iterative diagonalization of the Kohn-Sham Hamiltonian, Gaussian smearing of the population of partial occupancies with a width of $0.1 \mathrm{eV}$ was used to improve the convergence, and the total energy was extrapolated to absolute zero. The FeO/Pt(111) surface was simulated by the $(\sqrt{84} \times \sqrt{84}) R 10.9^{\circ}-\mathrm{FeO} / \mathrm{Pt}(111)$ superstructure from experiment [11], with a FeO film consisting of 67 oxygen and iron atoms and an oxygen overlayer of hexagonal symmetry supported on $\operatorname{Pt}(111)-(\sqrt{84} \times \sqrt{84})$ with three layer thickness. The $\mathrm{FeO}_{2} / \mathrm{Pt}(111)$ surface was constructed by adding an extra 670 atoms between the $\mathrm{Fe}$ and $\mathrm{Pt}$ atoms in such a way to form $\mathrm{O}-\mathrm{Fe}-\mathrm{O}$ fcc stacking with the same hexagonal symmetry and $(\sqrt{84} \times \sqrt{84}) R 10.9^{\circ}-\mathrm{FeO}_{2} / \mathrm{Pt}(111)$ superstructure. Only the $\Gamma$ point was considered for surface Brillouin zone sampling because of the large superstructure for both surfaces. The correction of the on-site Coulomb repulsion was made for iron using the DFT+U method [39] with the well tested values of $U=4$ and $J=1$ from the literature $[20,32,33,40]$. The initial magnetic structures of $\mathrm{FeO} / \mathrm{Pt}(111)$ and $\mathrm{FeO}_{2} / \mathrm{Pt}(111)$ were set to be antiferromagnetic. During the structure relaxation, all of the atoms were allowed to fully relax until the residual force was less than $0.3 \mathrm{eV} / \mathrm{nm}$, except for the bottom two Pt layers, which were fixed at the bulk truncated positions. Dipole corrections were applied to minimize the artificial interaction through the vacuum due to the periodicity. The work function was calculated by the difference between the vacuum energy level and the Fermi level. The oxidation states of the 0, Fe, and Pt atoms of interest and electron transfer were analyzed based on Bader charges $[41,42]$. To obtain the formal oxidation states, the calculated Bader charges were normalized based on the following bulk reference: $\mathrm{Fe}$ in body-centered-cubic (bcc) as $\mathrm{Fe}^{0}, \mathrm{Fe}$ in type-II antiferromagnetic (AFM-II) $\mathrm{FeO}$ as $\mathrm{Fe}^{2+}$ (ferrous state), $\mathrm{Fe}$ in $\alpha-\mathrm{Fe}_{2} \mathrm{O}_{3}$ as $\mathrm{Fe}^{3+}$ (ferric state).

\section{Results and discussion}

\subsection{Structure properties}

The FeO/Pt(111) superstructure has been extensively studied both experimentally and theoretically. Because of the lattice mismatch between FeO(111) (0.310 nm) and Pt(111) $(0.277$ $\mathrm{nm})$, a Moiré superstructure of $(\sqrt{84} \times \sqrt{84}) R 10.9^{\circ}-\mathrm{FeO} / \mathrm{Pt}(111)$ with periodicity of $2.54 \mathrm{~nm}$ forms (Fig. 1(a)). There are three domains inside the superstructure, denoted as the FCC, HCP, and TOP domains based on the adsorption site of the central interfacial $\mathrm{Fe}$ atoms on the $\mathrm{Pt}(111)$ surface. The $\mathrm{FeO}_{2} / \mathrm{Pt}(111)$ superstructure has not yet been well characterized. As an approximation, a trilayer O-Fe-O film on $\mathrm{Pt}(111)$ was constructed based on $(\sqrt{84} \times \sqrt{84}) R 10.9^{\circ}-\mathrm{FeO} / \mathrm{Pt}(111)$, in which an additional $\mathrm{O}$ layer was intercalated between the Fe layer and $\mathrm{Pt}$ layer to form $\mathrm{O}-\mathrm{Fe}-\mathrm{O}$ fcc stacking with the same hexagonal symmetry. The same FCC, HCP, and TOP domains are inherited from the $\mathrm{FeO}_{2} / \mathrm{Pt}(111)$ structure and used to distinguish the iron locations on the Pt substrate. All of the Fe cations are 6-fold coordinated by $\mathrm{O}$ anions, and all of the $\mathrm{O}$ atoms have three Fe neighbors.

The average of the calculated in-plane lattice constants $(\tilde{a})$ of $\mathrm{FeO}$ and $\mathrm{FeO}_{2}$ per cell are the same $(0.310 \mathrm{~nm})$. The $0-\mathrm{Fe}$

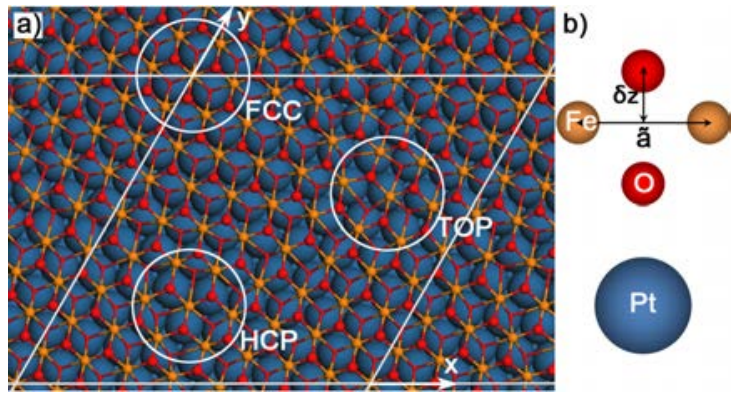

Fig. 1. (a) Schematic structure (top) of $\mathrm{FeO} / \mathrm{Pt}(111)$ and $\mathrm{FeO}_{2} / \mathrm{Pt}(111)$ superstructures with periodicity of $(\sqrt{84} \times \sqrt{84}) R 10.9^{\circ}$ indicated by a white parallelogram. The blue, red (large), red (small), and yellow spheres (color online) represent Pt, $\mathrm{O}$ (surface), $\mathrm{O}$ (interface), and $\mathrm{Fe}$ atoms, respectively. The $\mathrm{FeO} / \mathrm{Pt}(111)$ superstructure can be obtained by removing the small red spheres (interface oxygen atoms). The FCC, HCP, and TOP domains defined by the adsorption site of the central Fe atoms on $\mathrm{Pt}(111)$ are indicated by the white circles including the central seven iron cations. (b) Defined structural parameters of the in-plane lattice constant $\tilde{a}$ and the surface 0 -Fe rumpling $\delta_{\mathrm{z}}$ (side view) are indicated. 
surface rumpling $\left(\delta_{z}\right)$, which indicates the extent of the surface corrugation, is $0.067 \mathrm{~nm}$ for $\mathrm{FeO} / \mathrm{Pt}(111)$ (Table 1), and the pronounced rumpling leads to the $\mathrm{FeO} / \mathrm{Pt}(111)$ bilayer being polar. For $\mathrm{FeO}_{2} / \mathrm{Pt}(111), \delta_{\mathrm{z}}$ is $0.074 \mathrm{~nm}$, although the larger surface rumpling does not lead to the larger polarity of the $\mathrm{FeO}_{2} / \mathrm{Pt}(111)$ interface because of the symmetric O-Fe-O trilayer structure. The spatial separation $(d)$ between the grown oxide film and the Pt substrate is $0.234 \mathrm{~nm}$ for $\mathrm{FeO} / \mathrm{Pt}$ and $0.196 \mathrm{~nm}$ for $\mathrm{FeO}_{2} / \mathrm{Pt}$, and the calculated height difference between $\mathrm{FeO} / \mathrm{Pt}(111)$ and $\mathrm{FeO}_{2} / \mathrm{Pt}(111)$ is $0.087 \mathrm{~nm}$.

The heterogeneity of the superstructures for both the bilayer and trilayer films were determined from the domain-averaged structural parameters using the central seven $\mathrm{FeO}$ or $\mathrm{FeO}_{2}$ units of each domain, and are shown in Table 1. For FeO/Pt, the in-plane optimized lattice constants are 0.300 , 0.311 , and $0.316 \mathrm{~nm}$ for the FCC, HCP, and TOP domains, respectively. The corresponding O-Fe rumplings of the three domains are $0.077,0.068$, and $0.059 \mathrm{~nm}$, and the order of the corrugation is FCC > HCP > TOP. The difference of the 0-Fe rumpling between the three domains is less than $0.018 \mathrm{~nm}$, and the smaller the in-plane lattice constants, the larger the 0-Fe rumpling (corrugation). The calculated spatial separations $(d)$ between the FeO film and the Pt substrate are 0.222, 0.228, and $0.248 \mathrm{~nm}$ for the FCC, HCP, and TOP domains, respectively. These results agree well with our previous calculation [32]. The smaller separation for the FCC and HCP domains indicates a stronger interfacial interaction, which is due to stronger local coordination between interfacial Fe and the Pt substrate.

For $\mathrm{FeO}_{2} / \mathrm{Pt}$, the optimized in-plane lattice constants are $0.299,0.319$, and $0.329 \mathrm{~nm}$ for the FCC, HCP, and TOP domains, respectively. The corresponding surface $\mathrm{O}-\mathrm{Fe}$ rumpling values are $0.084,0.041$, and $0.051 \mathrm{~nm}$, and the order of the corrugation is FCC > TOP > HCP, which is different from FeO/Pt. Compared with $\mathrm{FeO} / \mathrm{Pt}$, although there is a correlation between the in-plane lattice constants and the surface corrugation, the surface corrugation of the $\mathrm{FeO}_{2} / \mathrm{Pt}$ surface is larger. In particular, the difference of the surface 0 -Fe rumpling between the three domains is $0.043 \mathrm{~nm}$, compared with $0.018 \mathrm{~nm}$ for FeO/Pt. The spatial separations of the $\mathrm{FeO}_{2}$ trilayer from the Pt substrate are $0.201,0.196$, and $0.180 \mathrm{~nm}$ for the FCC, HCP, and TOP domains, respectively. Compared with $\mathrm{FeO} / \mathrm{Pt}(111)$, the order of the spatial separations is reversed. This is because of the presence of interface oxygen atoms between Fe and Pt that sit on top of Pt atom for the FCC domain, which increases the interlayer spacing between the $\mathrm{Fe}$ and $\mathrm{Pt}$ atoms. These different structural characteristics of $\mathrm{FeO} / \mathrm{Pt}$ and $\mathrm{FeO}_{2} / \mathrm{Pt}$ affect the cor-

\section{Table 2}

Calculated cell-averaged electronic properties of $\mathrm{FeO} / \mathrm{Pt}(111)$ and $\mathrm{FeO}_{2} / \mathrm{Pt}(111)$ including the work function change $\Delta \Phi$ (in eV) with respect to Pt(111), surface Pt and Fe charge states $(e)$, and the calculated interfacial adhesion energy $E_{\text {adh }}(\mathrm{eV} / \mathrm{Fe})$ between $\mathrm{FeO}\left(\right.$ or $\left.\mathrm{FeO}_{2}\right)$ and $\operatorname{Pt}(111)$.

\begin{tabular}{lcccc}
\hline & $\Delta \Phi$ & Pt charge & Fe charge & $E_{\text {adh }}$ \\
\hline $\mathrm{FeO} / \mathrm{Pt}$ & -0.02 & -0.27 & +2.36 & 1.40 \\
$\mathrm{FeO}_{2} / \mathrm{Pt}$ & 1.24 & +0.26 & +2.95 & 1.66 \\
\hline
\end{tabular}

responding electronic properties and oxygen activity, which will be described below.

\section{2. $\quad$ Electronic properties}

We first calculated the normalized Bader charges of iron for both surfaces (Table 2). For FeO/Pt, the average calculated Bader charge of iron was +2.36 . This means that the apparent oxidation state of iron is between the ferrous and ferric state. The higher oxidation state than the ferrous state for the $\mathrm{FeO}$ stoichiometry is due to overall net charge transfer from the interfacial Fe to the Pt substrate of 0.27 |e| per surface Pt atom. This can be rationalized by the high electronegativity of $\mathrm{Pt}$ compared with $\mathrm{Fe}$. For $\mathrm{FeO}_{2} / \mathrm{Pt}$, the calculated Bader charge is +2.95 , which is close to the ferric state. Although the higher oxidation state than $\mathrm{FeO} / \mathrm{Pt}$ is consistent with the higher $\mathrm{O}-\mathrm{Fe}$ ratio, the oxidation state is still less than +4 , as is expected from the stoichiometry of $\mathrm{FeO}_{2}$. Further analysis reveals that the reason for a net charge transfer of 0.26 |e| per surface $\mathrm{Pt}$ atom from $\mathrm{Pt}$ to the supported $\mathrm{FeO}_{2}$ is reverse charge transfer because of the higher electronegativity of the interfacial 0 than Pt.

The calculated work functions $(\Delta \Phi)$ with respect to $\operatorname{Pt}(111)$ are also shown in Table 2. The $\Delta \Phi$ values are $-0.02 \mathrm{eV}$ for $\mathrm{FeO} / \mathrm{Pt}(111)$ and $1.24 \mathrm{eV}$ for $\mathrm{FeO}_{2} / \mathrm{Pt}(111)$. It has been reported that ultra-thin oxide films can greatly influence the surface work function because of interplay of the charge transfer and the dipole moment of surface relaxation induced by the formation of the interface bonds $[43,44]$. For FeO/Pt(111), the net charge transfer from $\mathrm{FeO}$ to $\mathrm{Pt}$ would induce a dipole moment away from the substrate and decreases the work function. However, the 0 -Fe rumpling $(0.067 \mathrm{~nm})$ would generate an opposite dipole moment and increase the work function. These two factors would cancel each other and lead to a small change in the work function for $\mathrm{FeO} / \mathrm{Pt}(111)$ with respect to $\mathrm{Pt}(111)$. In contrast, for $\mathrm{FeO}_{2} / \mathrm{Pt}(111)$, the overall net charge transfer from $\mathrm{Pt}$ to $\mathrm{FeO}_{2}$ would induce a dipole moment pointing towards the substrate and increase the work function, and there

Table 1

Calculated structural properties of $\mathrm{FeO} / \mathrm{Pt}(111)$ and $\mathrm{FeO}_{2} / \mathrm{Pt}(111)$ superstructures with periodicity of $(\sqrt{8} 4 \times \sqrt{84}) R 10.9^{\circ}$.

\begin{tabular}{|c|c|c|c|c|c|c|c|c|}
\hline \multirow{2}{*}{ Domain } & \multicolumn{4}{|c|}{$\mathrm{FeO} / \mathrm{Pt}(111)$} & \multicolumn{4}{|c|}{$\mathrm{FeO}_{2} / \mathrm{Pt}(111)$} \\
\hline & $\tilde{a} / \mathrm{nm}$ & $d / \mathrm{nm}$ & $\delta_{\mathrm{z}} / \mathrm{nm}$ & $V_{\mathrm{z}} / \mathrm{eV}$ & $\tilde{a} / \mathrm{nm}$ & $d / \mathrm{nm}$ & $\delta_{z} / \mathrm{nm}$ & $V_{z} / \mathrm{eV}$ \\
\hline Average & 0.310 & 0.234 & 0.067 & 5.77 & 0.310 & 0.196 & 0.074 & 6.89 \\
\hline FCC & 0.300 & 0.222 & 0.077 & 5.99 & 0.299 & 0.201 & 0.084 & 7.15 \\
\hline HCP & 0.311 & 0.228 & 0.068 & 5.78 & 0.319 & 0.196 & 0.041 & 6.64 \\
\hline TOP & 0.316 & 0.248 & 0.059 & 5.51 & 0.329 & 0.180 & 0.051 & 6.72 \\
\hline
\end{tabular}

$\tilde{a}$ is the in-plane $\mathrm{FeO}\left(\right.$ or $\mathrm{FeO}_{2}$ ) lattice parameter; $d$ is the spatial separation between the bottom of the supported oxide film and Pt(111) substrate; $\delta_{z}$ is the surface $\mathrm{O}-\mathrm{Fe}$ rumpling; $V_{\mathrm{z}}$ is the surface electrostatic potential at a height of $0.44 \mathrm{~nm}$ from the topmost oxygen (referencing the corresponding Fermi level). The first row is the cell-averaged value for the whole superstructure, and the domain-averaged results are given below. 
is no significant polarity for the symmetrical O-Fe-O trilayer on Pt. Therefore, it is mainly the charge transfer that is responsible for the large increase in the work function of $\mathrm{FeO}_{2} / \mathrm{Pt}(111)$.

Further insight into the different electronic properties of $\mathrm{FeO} / \mathrm{Pt}(111)$ and $\mathrm{FeO}_{2} / \mathrm{Pt}(111)$ can be obtained from the surface electrostatic potential, in particular the dependence on the domains of $\mathrm{FeO} / \mathrm{Pt}$ and $\mathrm{FeO}_{2} / \mathrm{Pt}$. The corresponding electrostatic potentials $V_{\mathrm{z}}$ (the Fermi level is the zero value) at the height of $0.44 \mathrm{~nm}$ from the topmost surface 0 atoms are on average $5.77 \mathrm{eV}$ for $\mathrm{FeO} / \mathrm{Pt}(111)$ and $6.89 \mathrm{eV}$ for $\mathrm{FeO}_{2} / \mathrm{Pt}(111)$. The smaller electrostatic potential for $\mathrm{FeO} / \mathrm{Pt}$ is due to its lower surface work function, as discussed above.

The spatial-resolved contour plots of the calculated $V_{\mathrm{z}}$ for $\mathrm{FeO} / \mathrm{Pt}$ and $\mathrm{FeO}_{2} / \mathrm{Pt}$ are shown in Fig. 2. For FeO/Pt (Fig. 2(a)), three distinct domains can be seen. The FCC domain has the highest electrostatic potential (green) and the TOP domain has the lowest (blue). The domain-averaged $V_{\mathrm{z}}$ values (Table 1) are $5.99 \mathrm{eV}$ (FCC) $>5.78 \mathrm{eV}$ (HCP) $>5.51 \mathrm{eV}$ (TOP). The order of $V_{\mathrm{z}}$ in the three domains is the same as that of the surface corrugation. However, the contour plot of the calculated $V_{\mathrm{z}}$ of $\mathrm{FeO}_{2} / \mathrm{Pt}(111$ ) (Fig. 2(b)) is slightly different. The FCC domain has the highest electrostatic potential and the largest area, while the HCP and TOP domains have a lower but similar electrostatic potential. The corresponding domain-averaged $V_{\mathrm{z}}$ values are $7.15 \mathrm{eV}$ (FCC) $>6.72 \mathrm{eV}$ (TOP) $>6.64 \mathrm{eV}$ (HCP). It is interesting to note that the order of $V_{\mathrm{z}}$ is again the same as the order of the corrugation. These results clearly show that the surface corrugation affects the surface electrostatic potential.

\subsection{Oxygen activity}

The distinct structural and electronic properties of $\mathrm{FeO} / \mathrm{Pt}$ and $\mathrm{FeO}_{2} / \mathrm{Pt}$ affect the oxygen activity and the corresponding stability of the ultrathin oxide films. Here, the oxygen activity is measured by the differentiate binding energy of oxygen with respect to the oxygen molecule in the gas phase $\left(E_{\mathrm{b}}\right)$ :

$$
E_{\mathrm{b}}=E_{0}-E_{1}-0.5 \times E\left(\mathrm{O}_{2}\right)
$$

where $E_{0}, E_{1}$, and $E\left(\mathrm{O}_{2}\right)$ are the total energies of $\mathrm{FeO} / \mathrm{Pt}(111)$ (or $\mathrm{FeO}_{2} / \mathrm{Pt}(111)$ ), the corresponding structure with oxygen vacancy defect, and $\mathrm{O}_{2}$ in gas phase, respectively. To save on computational cost, no structural relaxations were performed for the defective structures, and the calculated results are shown in Fig. 3. For $\mathrm{FeO} / \mathrm{Pt}(111)$, the calculated domain-averaged differentiate binding energies are $-3.08 \mathrm{eV} / 0$

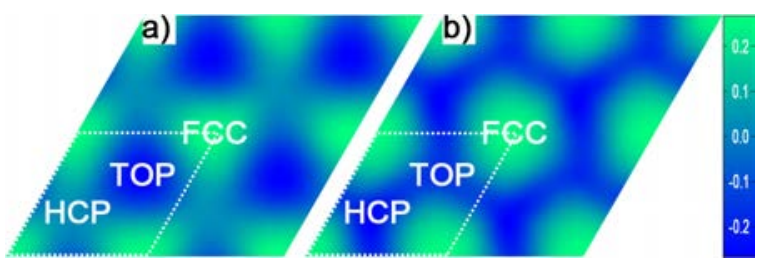

Fig. 2. Contour plots of the electrostatic potential $V_{\mathrm{z}}$ (in $\mathrm{eV}$ ) of $\mathrm{FeO} / \mathrm{Pt}\left(111\right.$ ) (a) and $\mathrm{FeO}_{2} / \mathrm{Pt}(111$ ) (b) at an average height of $0.44 \mathrm{~nm}$ from the surface oxygen layer. The reference is the cell-averaged electrostatic potential $(5.77 \mathrm{eV}$ for $\mathrm{FeO} / \mathrm{Pt}(111)$ and $6.89 \mathrm{eV}$ for $\mathrm{FeO}_{2} / \mathrm{Pt}(111)$ ). The corresponding FCC, HCP, and TOP domains are indicated.

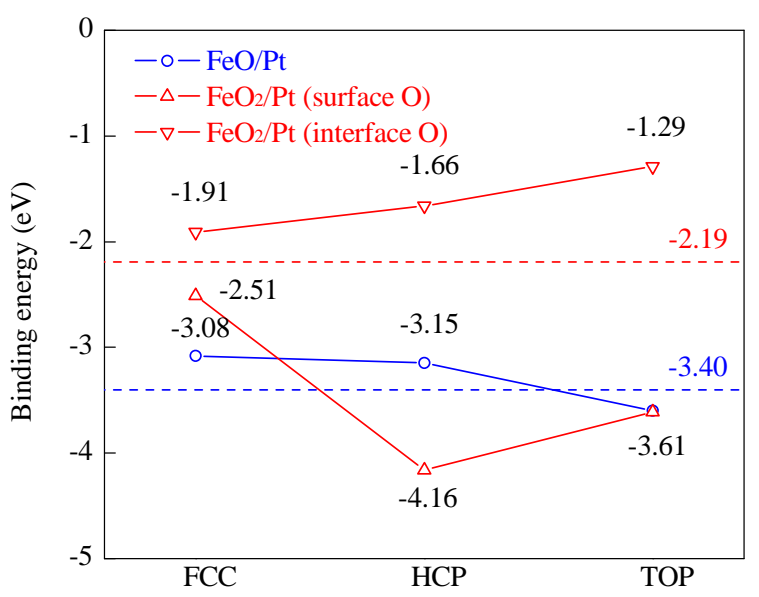

Fig. 3. Calculated differentiate binding energies (in eV) of oxygen of $\mathrm{FeO} / \mathrm{Pt}(111)$ (blue circles), and surface oxygen (red up-triangle) and interface oxygen (red down-triangle) of $\mathrm{FeO}_{2} / \mathrm{Pt}(111)$ for the different domains. The blue $(\mathrm{FeO} / \mathrm{Pt})$ and red $\left(\mathrm{FeO}_{2} / \mathrm{Pt}\right)$ dashed lines (color online) indicate the cell average values. The numerical results are also shown.

(FCC), -3.15 eV/O (HCP), and $-3.60 \mathrm{eV} / 0$ (TOP). The cell-averaged binding energy is $-3.40 \mathrm{eV} / 0$. All of the binding energies are energetically favorable, as expected from the high activity of iron. The order of the oxygen activity (FCC > HCP > TOP) follows the same order as the surface corrugation. This can be explained by larger surface corrugation (larger $\mathrm{O}-\mathrm{Fe}$ rumpling) leading to larger polarity and lateral repulsion, which results in smaller differentiate binding energy (higher activity).

For $\mathrm{FeO}_{2} / \mathrm{Pt}(111)$, the calculated differentiate binding energies of the surface oxygen are $-2.51 \mathrm{eV} / \mathrm{O}$ (FCC), $-4.16 \mathrm{eV} / 0$ (HCP), and $-3.61 \mathrm{eV} / 0$ (TOP). The order of the oxygen activity (FCC $>$ TOP $>$ HCP) again follows the same order as the surface corrugation. The calculated differentiate binding energies for the interfacial oxygen atoms are $-1.91 \mathrm{eV} / \mathrm{O}$ (FCC), $-1.66 \mathrm{eV} / 0$ (HCP), and $-1.29 \mathrm{eV} / 0$ (TOP), which are all much smaller than those of the corresponding surface oxygen atoms. The weaker binding of the interface oxygen is due to the additional deformation cost for the intercalation of oxygen between $\mathrm{Fe}$ and $\mathrm{Pt}$. The cell-averaged binding energy is $-2.19 \mathrm{eV} / \mathrm{O}$, which is much weaker than that of $\mathrm{FeO} / \mathrm{Pt}(111)$. The calculated interfacial adhesion energy between $\mathrm{FeO}$ and $\mathrm{Pt}(111)$ is $1.40 \mathrm{eV}$ per $\mathrm{Fe}$ atom, whereas for $\mathrm{FeO}_{2} / \mathrm{Pt}(111)$ it is $1.66 \mathrm{eV}$ per Fe atom (Table 2). Although both show significant interfacial adhesion, the nature of the bonding is different: for $\mathrm{FeO} / \mathrm{Pt}(111)$, it originates from the Fe-Pt interaction, while for $\mathrm{FeO}_{2} / \mathrm{Pt}(111)$, it originates from the 0-Pt interaction.

To oxidize $\mathrm{FeO} / \mathrm{Pt}(111)$ to $\mathrm{FeO}_{2} / \mathrm{Pt}(111)$ under the higher oxygen chemical potential,

$$
\begin{gathered}
\mu_{0}=0.5 \times\left(E\left(\mathrm{O}_{2}\right)+\Delta \mu_{02}\left(T, p^{\circ}\right)+k_{\mathrm{B}} T \ln \left(p_{02} / p^{\circ}\right)\right) \\
=0.5 \times E\left(\mathrm{O}_{2}\right)+\Delta \mu_{0}\left(T, p_{02}\right),
\end{gathered}
$$

It requires the corresponding Gibbs free energy of formation $\Delta G\left(\mathrm{FeO}_{2} / \mathrm{Pt}\right)$, referring to $\mathrm{FeO} / \mathrm{Pt}$ to be exothermic $[45,46]$.

$$
\begin{gathered}
\Delta G\left(\mathrm{FeO}_{2} / \mathrm{Pt}\right) \approx\left(E\left(\mathrm{FeO}_{2} / \mathrm{Pt}\right)-E(\mathrm{FeO} / \mathrm{Pt})-\right. \\
\left.0.5 \times N \times E\left(\mathrm{O}_{2}\right)-N \times \Delta \mu_{0}\left(T, p_{02}\right)\right) / A,
\end{gathered}
$$

where $E\left(\mathrm{FeO}_{2} / \mathrm{Pt}\right), E(\mathrm{FeO} / \mathrm{Pt})$, and $E\left(\mathrm{O}_{2}\right)$ are the total energies 


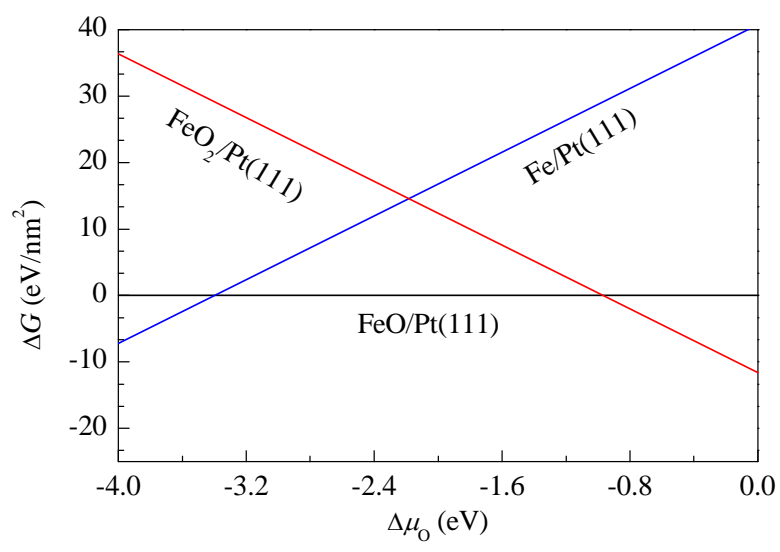

Fig. 4. Calculated Gibbs free energy of formation of $\mathrm{FeO}_{2} / \mathrm{Pt}(111)$ (red line) and $\mathrm{Fe} / \mathrm{Pt}(111)$ (blue line) with respect to $\mathrm{FeO} / \mathrm{Pt}(111)$ (black line) plotted against the oxygen chemical potential $\Delta \mu_{0}$.

of $\mathrm{FeO}_{2} / \mathrm{Pt}, \mathrm{FeO} / \mathrm{Pt}$, and $\mathrm{O}_{2}$ from DFT, $N$ is the number of extra oxygen atoms added in the $\mathrm{FeO} / \mathrm{Pt}$ superstructure, and $A$ is the corresponding surface area. Under high temperature or low oxygen partial pressure, $\mathrm{FeO}$ on $\mathrm{Pt}(111)$ decomposes to metallic Fe when the corresponding Gibbs free energy of formation $(\Delta G(\mathrm{Fe} / \mathrm{Pt}))$ is exothermic.

$$
\begin{gathered}
\Delta G(\mathrm{Fe} / \mathrm{Pt}) \approx\left(E(\mathrm{Fe} / \mathrm{Pt})-E(\mathrm{FeO} / \mathrm{Pt})+0.5 \times N \times E\left(\mathrm{O}_{2}\right)+\right. \\
\left.N \times \Delta \mu_{0}\left(T, p_{02}\right)\right) / A,
\end{gathered}
$$

where $E(\mathrm{Fe} / \mathrm{Pt})$ is the total energy of the optimized Fe/Pt(111) surface without the presence of the oxygen overlayer of $\mathrm{FeO} / \mathrm{Pt}(111)$.

The calculated $\Delta G\left(\mathrm{FeO}_{2} / \mathrm{Pt}\right)$ and $\Delta G(\mathrm{Fe} / \mathrm{Pt})$ values plotted against the oxygen chemical potential $\left(\Delta \mu_{0}\right)$ are shown in Fig. 4. From this figure, it can be determined that $\mathrm{FeO} / \mathrm{Pt}$ is the most favorable in a relatively large range of $\Delta \mu_{0}$ from -3.40 to -0.97 $\mathrm{eV}$. When $\Delta \mu_{0} \geq-0.97 \mathrm{eV}, \mathrm{FeO} / \mathrm{Pt}$ will be oxidized to $\mathrm{FeO}_{2} / \mathrm{Pt}$. When $\Delta \mu_{0}$ is less than $-3.40 \mathrm{eV}, \mathrm{FeO}$ will decompose to $\mathrm{Fe} / \mathrm{Pt}$, and the metallic Fe will further diffuse towards the subsurface region. Indeed, it has been found by experiment [22] that under $2000 \mathrm{~Pa}$ of $\mathrm{O}_{2}$ at $450 \mathrm{~K}$ (equivalent to $\Delta \mu_{0} \approx-0.51 \mathrm{eV}$ ), the pre-prepared $\mathrm{FeO} / \mathrm{Pt}(111)$ film oxidized to an ordered O-rich film. Although the structure of the 0-rich film remains, it was speculated that a O-Fe-O trilayer structure formed on $\mathrm{Pt}(111)$. This is supported by the present work. The STM line scan found that the apparent height of the 0-rich film was $0.065 \mathrm{~nm}$ higher than that of $\mathrm{FeO} / \mathrm{Pt}(111)$, which is close to the calculated height difference of $0.087 \mathrm{~nm}$ between $\mathrm{FeO}_{2} / \mathrm{Pt}(111)$ and $\mathrm{FeO} / \mathrm{Pt}(111)$. Moreover, the oxygen chemical potential of -0.51 $\mathrm{eV}$ applied to form the 0-rich film is already larger than that predicted from the calculation $(-0.97 \mathrm{eV})$ required for the formation of $\mathrm{FeO}_{2} / \mathrm{Pt}(111)$. Thermal desorption spectra (TDS) of $\mathrm{FeO} / \mathrm{Pt}(111)$ [22] found that there was a single $\mathrm{O}_{2}$ desorption peak at $1170 \mathrm{~K}$ for the $\mathrm{FeO}$ film, whereas for the 0-rich film there were two peaks at 840 and $1190 \mathrm{~K}$. The two desorption peaks can be attributed to the interface oxygen having a weaker binding energy than the surface oxygen of $\mathrm{FeO}_{2} / \mathrm{Pt}(111)$.

\section{Conclusions}

A systematic DFT study of bilayer FeO/Pt(111) and trilayer
$\mathrm{FeO}_{2} / \mathrm{Pt}(111)$ was performed based on the realistic superstructures found by experiment. It is found that the two ultrathin oxide films have distinct structural properties, electronic properties, and oxygen activity, which sensitively depend on the registries with the Pt substrate. For Fe0/Pt(111), the order of the surface corrugation for the different domains is FCC $>$ HCP $>$ TOP, whereas it is FCC > TOP > HCP for $\mathrm{FeO}_{2} / \mathrm{Pt}(111)$. Compared with $\mathrm{FeO} / \mathrm{Pt}(111), \quad \mathrm{FeO}_{2} / \mathrm{Pt}(111)$ shows more pronounced surface corrugation. The surface corrugation affects not only the local electrostatic potentials but also the corresponding oxygen binding energies: the larger the surface corrugation, the higher the electrostatic potential/the weaker the oxygen binding. There is a net charge transfer from $\mathrm{FeO}$ to $\mathrm{Pt}$ for $\mathrm{FeO} / \mathrm{Pt}(111)$, and the corresponding oxidation state of iron is slightly higher than the ferrous state. The polarity of the supported $\mathrm{FeO}$ bilayer is opposite to the dipole from the charge transfer, and this results in a negligible change of the surface work function of $\mathrm{FeO} / \mathrm{Pt}(111)$ with respect to $\mathrm{Pt}(111)$. In contrast, for the nonpolar $\mathrm{FeO}_{2}$ trilayer on $\mathrm{Pt}(111)$, there is charge transfer from $\mathrm{Pt}$ to the supported $\mathrm{FeO}_{2}$ film. This generates a ferric state of iron in $\mathrm{FeO}_{2} / \mathrm{Pt}(111)$, and significantly increases the surface work function. The interplay between the polarity of the supported ultrathin oxide films and the charge transfer with respect to the metal substrates and its influence on the surface electronic properties are highlighted.

\section{References}

[1] Street S C, Xu C, Goodman D W. Annu Rev Phys Chem, 1997, 48: 43

[2] Rainer D R, Goodman D W. J Mol Catal A, 1998, 131: 259

[3] Freund H-J. Surf Sci, 2007, 601: 1438

[4] Nilius N. Surf Sci Rep, 2009, 64: 595

[5] Netzer F P, Allegretti F, Surnev S. J Vac Sci Technol B, 2010, 28: 1

[6] Nilius N, Risse T, Schauermann S, Shaikhutdinov S, Sterrer M, Freund H J. Top Catal, 2011, 54: 4

[7] Su H-Y, Gu X-K, Ma X, Zhao Y-H, Bao X-H, Li W-X. Catal Today, 2011, 165: 89

[8] Mu R, Fu Q Xu H, Zhang H, Huang Y, Jiang Z, Zhang S, Tan D, Bao X. J Am Chem Soc, 2011, 133: 1978

[9] Sun D, Gu X-K, Ouyang R, Su H-Y, Fu Q, Bao X, Li W-X.J Phys Chem C, 2012, 116: 7491

[10] Shaikhutdinov S, Freund H J. Annu Rev Phys Chem, 2012, 63: 619.

[11] Ritter M, Ranke W, Weiss W. Phys Rev B, 1998, 57: 7240

[12] Ranke W, Ritter M, Weiss W. Phys Rev B, 1999, 60: 1527

[13] Chambers S A. Surf Sci Rep, 2000, 39: 105

[14] Schintke S, Schneider W-D.J Phys: Condens Matter, 2004, 16: R49

[15] Kresse G. Science, 2005, 308: 1440

[16] Agnoli S, Sambi M, Granozzi G, Schoiswohl J, Surnev S, Netzer F P, Ferrero M, Ferrari A M, Pisani C. J Phys Chem B, 2005, 109: 17197

[17] Ma T, Fu Q, Su H-Y, Liu H-Y, Cui Y, Wang Z, Mu R-T, Li W-X, Bao X-H. ChemPhysChem, 2009, 10: 1013

[18] Yao Y, Fu Q, Wang Z, Tan D, Bao X. J Phys Chem C, 2010, 114: 17069

[19] Sankaranarayanan S K R S, Ramanathan S. J Phys Chem C, 2010, 114: 6631

[20] Zhang W, Li Z, Luo Y, Yang J.J Phys Chem C, 2009, 113: 8302

[21] Giordano L, Lewandowski M, Groot I M N, Sun Y N, Goniakowski J, Noguera C, Shaikhutdinov S, Pacchioni G, Freund H J.J Phys Chem C, 2010, 114: 21504

[22] Sun Y-N, Giordano L, Goniakowski J, Lewandowski M, Qin Z-H, 


\title{
Graphical Abstract
}

Chin. J. Catal., 2013, 34: 973-978 doi: 10.1016/S1872-2067(12)60580-4

\section{A first-principles study of the structure, electronic properties, and} oxygen binding of $\mathrm{FeO} / \mathrm{Pt}(111)$ and $\mathrm{FeO}_{2} / \mathrm{Pt}(111)$

SUN Dapeng, LI Weixue*

Dalian Institute of Chemical Physics, Chinese Academy of Sciences

Ultrathin oxide films of iron oxides on Pt(111) were studied by DFT, and the importance of the surface corrugation on the relevant electronic properties and surface oxygen activities is highlighted.

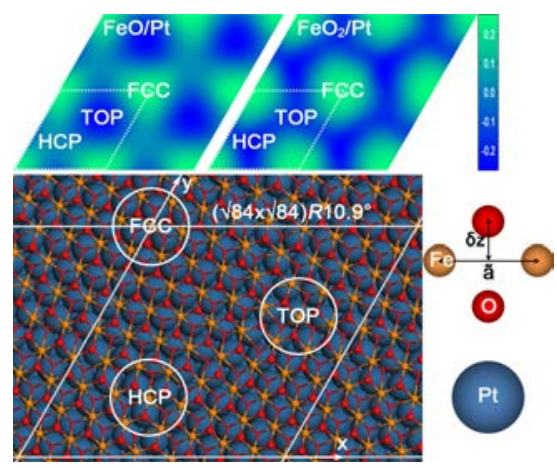

Noguera C, Shaikhutdinov S, Pacchioni G, Freund H-J. Angew Chem Int Ed, 2010, 49: 4418

[23] Fu Q, Li W X, Yao Y X, Liu H Y, Su H Y, Ma D, Gu X K, Chen L M, Wang Z, Zhang H, Wang B, Bao X H. Science, 2010, 328: 1141

[24] Merte L R, Knudsen J, Eichhorn F M, Porsgaard S, Zeuthen H, Grabow L C, Laegsgaard E, Bluhm H, Salmeron M, Mavrikakis M, Besenbacher F. J Am Chem Soc, 2011, 133: 10692

[25] Ringleb F, Fujimori Y, Wang H-F, Ariga H, Carrasco E, Sterrer M, Freund H-J, Giordano L, Pacchioni G, Goniakowski J.J Phys Chem C, 2011, 115: 19328

[26] Jung J, Shin H-J, Kim Y, Kawai M. J Am Chem Soc, 2011, 133: 6142

[27] Monti M, Santos B, Mascaraque A, Rodriguez d I F O, Nino M A, Mentes T 0, Locatelli A, McCarty K F, Marco J F, de I F J. J Phys Chem C, 2012, 116: 11539

[28] Spiridis N, Wilgocka-Slezak D, Freindl K, Figarska B, Giela T, Mlynczak E, Strzelczyk B, Zajac M, Korecki J. Phys Rev B, 2012, 85: 075436

[29] Gu X-K, Ouyang R, Sun D, Su H-Y, Li W-X. ChemSusChem, 2012, 5: 871

[30] Merte L R, Grabow L C, Peng G, Knudsen J, Zeuthen H, Kudernatsch W, Porsgaard S, Lægsgaard E, Mavrikakis M, Besenbacher F. J Phys Chem C, 2011, 115: 2089
[31] Lewandowski M, Groot I M N, Shaikhutdinov S, Freund H J. Catal Today, 2012, 181: 52

[32] Ouyang R, Li W-X. Phys Rev B, 2011, 84: 165403

[33] Giordano L, Pacchioni G, Goniakowski J, Nilius N, Rienks E D L, Freund H J. Phys Rev B, 2007, 76: 075416

[34] Kresse G, Hafner J. Phys Rev B, 1993, 48: 13115

[35] Kresse G, Furthmuller J. Phys Rev B, 1996, 54: 11169

[36] Blochl P E. Phys Rev B, 1994, 50: 17953

[37] Kresse G, Joubert D. Phys Rev B, 1999, 59: 1758

[38] Perdew J P, Chevary J A, Vosko S H, Jackson K A, Pederson M R, Singh D J, Fiolhais C. Phys Rev B, 1992, 46: 6671

[39] Dudarev S L, Botton G A, Savrasov S Y, Humphreys C J, Sutton A P. Phys Rev B, 1998, 57: 1505

[40] Rollmann G, Rohrbach A, Entel P, Hafner J. Phys Rev B, 2004, 69: 165107

[41] Bader R F W. Chem Rev, 1991, 91: 893

[42] Tang W, Sanville E, Henkelman G.J Phys Condens Matter, 2009, 21: 084204

[43] Giordano L, Cinquini F, Pacchioni G. Phys Rev B, 2006, 73: 045414

[44] Prada S, Martinez U, Pacchioni G. Phys Rev B, 2008, 78: 235423

[45] Reuter K, Scheffler M. Phys Rev B, 2002, 65: 035406

[46] Li W-X, Stampfl C, Scheffler M. Phys Rev Lett, 2003, 90: 256102

\section{$\mathrm{FeO} / \mathrm{Pt}(111)$ 与 $\mathrm{FeO}_{2} / \mathrm{Pt}(111)$ 的几何、电子结构及表面氧活性的第一性原理研究}

\author{
孙大鹏, 李微雪* \\ 中国科学院大连化学物理研究所催化基础国家重点实验室, 辽宁大连116023
}

摘要: 采用密度泛函理论系统研究了超薄氧化物膜/金属体系 $\mathrm{FeO} / \mathrm{Pt}$ 和 $\mathrm{FeO}_{2} / \mathrm{Pt}$ 及其表面不同区域(FCC, HCP和TOP)的几何结构、 电子性质及氧的活性. 研究发现, 表面 $\mathrm{O}-\mathrm{Fe}$ 高度差 $\delta_{z}$ 作为一个重要的特征结构参数直接影响局域表面静电势和表面氧的结合能: $\delta_{\mathrm{z}}$ 越大, 静电势越大, 氧的结合能越弱. 计算发现, 在 FeO/Pt体系中, $\delta_{\mathrm{z}}$ 顺序为FCC $>\mathrm{HCP}>\mathrm{TOP}$, 而FeO $/$ Pt中是FCC $>\mathrm{TOP}>\mathrm{HCP}$. 此外, 在 $\mathrm{FeO} / \mathrm{Pt}$ 中, 电荷转移方向是从氧化物膜到补底, $\mathrm{Fe}$ 的表观价态为 +2.36 , 表面功函较纯 $\mathrm{Pt}(111)$ 的变化可忽略; 而 $\mathrm{FeO}_{2} / \mathrm{Pt}$ 中, 电荷转移的方向是从祄底到氧化物, Fe的表观价态为 +2.95 , 表面功函较纯Pt增加 $1.24 \mathrm{eV}$. 进一步分析了电荷转移和表面偶极对电 子性质的作用机制. 这些研究结果对于认识超薄氧化物薄膜对表面几何结构、电子性质、表面氧活性的调制具有重要的启示意 义.

关键词: 超薄氧化物膜; 超结构; 表面褶皱; 电荷转移; 功函

收稿日期: 2013-01-26. 接受日期: 2013-03-15. 出版日期: 2013-05-20.

*通讯联系人. 电话: (0411)84379996; 传真: (0411)84694447; 电子信箱: wxli@dicp.ac.cn

基金来源：国家自然科学基金(21225315, 21173210); 国家重点基础研究发展计划(973计划, 2013CB834603).

本文的英文电子版由Elsevier出版社在ScienceDirect上出版(http://www.sciencedirect.com/science/journal/18722067). 